UDC 539.3

\title{
ANALYSIS OF THE STRESSED-STRAINED STATE OF THE FOUNDATION-SHELL AT INTERACTION WITH THE ELASTIC- PLASTIC MEDIUM
}

\author{
M.O. Vabishchevich, \\ DSc, Department of Structural mechanics \\ Gh.A. Zatyliuk, \\ Postgraduate student, Department of Structural mechanics \\ Kyiv National University of Construction and Architecture \\ 31, Povitroflotsky ave., Kyiv, Ukraine, 03037
}

DOI: $10.32347 / 2410-2547.2021 .106 .105-112$

\begin{abstract}
On the basis of modern numerical implementations of the finite element method the article presents the justification of the adequacy of the method of solving the problems of structures straining in their contact interaction with the elastic-plastic nonlinear soil medium.

Taking into account the method of construction of computational models of joint straining and mutual influence of rigid structures and essentially plastic external medium allows specifying essentially the stress state of structures interacting with the soil base, and has a visible effect on the calculated level of the base bearing capacity.

Keywords: elastic-plastic medium, finite element method, semi-analytical finite element method, structure straining problem.
\end{abstract}

Introduction. Compatible calculations of structures and nonlinear bases, which are described by modern mechanical and soil models within one problem is a significant technical problem.

The solution of the assigned tasks is possible only within the framework of numerical methods, the most common of which is the finite element method (FEM) [10]. The construction of the computational finite element model raises many complex questions that require additional detailed study. In addition, the compliance with the state building norms and regulations is an important factor for further practical use.

The combination of the latest achievements in the field of structural mechanics and soil mechanics is a promising direction for the development of effective approaches to building discrete models of space systems "structurenonlinear base" for solving applied problems.

On the basis of modern numerical implementations of the finite element method the article presents the theoretical foundations of the analysis of straining processes of machines and structures in their contact interaction with the elastic-plastic nonlinear soil medium within the three-dimensional spatial problem taking into account the previous stress state and load history. The methodology of construction of computational models of joint straining and mutual influence of rigid structures and essentially plastic external medium is developed, new special heterogeneous finite elements of SAFEM of general form with variable geometrical and physical-mechanical parameters and

Vabishchevich M.O., Zatyliuk Gh.A. 
arbitrary boundary conditions for approximation of arrays of hardly connected reinforced soils are developed.

The purpose of the article is to substantiate the proposed method adequacy [11] to solve the problems of structures straining in their contact interaction with the elastic-plastic nonlinear soil medium.

Numerical simulation of sand sample tests in a compression device. Based on the data presented in [9], the following parameters of the soil deformation modulus $E=5.6 \mathrm{MPa}$, the structural strength $\sigma_{\mathrm{m} 1}=0.03 \mathrm{MPa}$, the compression ratio $C_{c}=0.0065$, the density $p_{0}=1730 \mathrm{~kg} / \mathrm{m} 3$, the porosity $e_{0}=0.68$

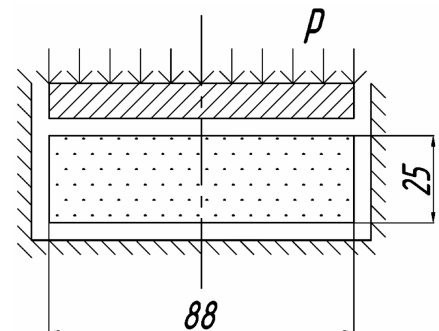

Fig.1. Sample geometric parameters in the numerical simulation of compression tests are accepted. In addition, it was assumed that the Poisson's ratio $v=0.3$, the specific adhesion $c=1 \mathrm{kPa}$ and the internal friction angle $\varphi_{0}=32^{\circ}$. The sample dimensions are shown in Fig. 1.

The difference between the computational and experimental values of porosity does not exceed $0.2 \%$ (Fig. 2, curve 1). It should be noted that the model initial variant $[2,3,8]$, where this method is not used, leads to the porosity-pressure line graph (Fig. 2, curve 2), i.e. does not even qualitatively approach the experimental data of compression tests. The comparison of the loaddisplacement graphs (Fig. 3) for the proposed (1) and initial (2) variants of the soil straining model shows that under conditions of heterogeneous triaxial compression when reaching the method structural strength first reduces the computational stiffness of the soil sample. Then, with increasing hydrostatic pressure, the reverse process begins - the sample stiffness increases and exceeds the initial one.

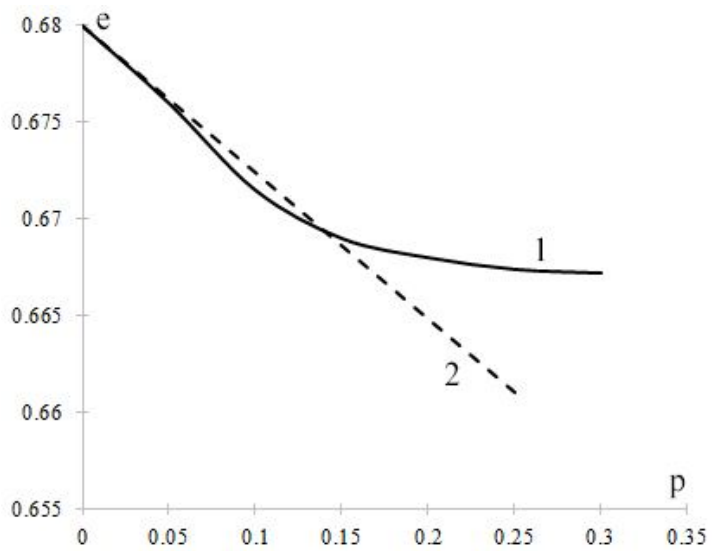

Fig. 2. Compression curve in the numerical simulation of compression tests 


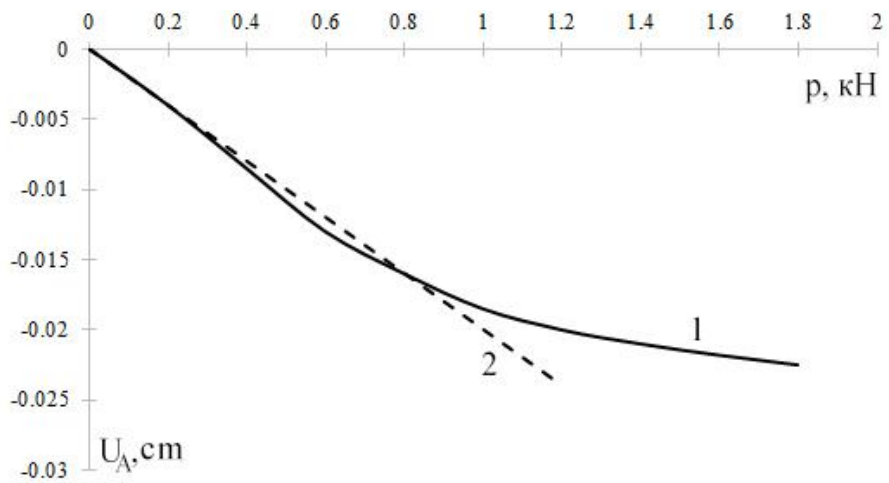

Fig. 3. Load-displacement graph in the numerical simulation of compression tests

Foundation-shell calculation. To demonstrate the possibilities of the developed method of numerical modeling of the structures interaction with a nonlinear base, the foundation-shell calculation was executed, the results of which are compared with the data of full-scale tests described in [7].

The conical foundation-shell (Fig. 4) with the base diameter of $3 \mathrm{~m}$ had the conicity angle $\alpha=5$ and the constant thickness $h=17 \mathrm{~cm}$. The base was the loam with the internal friction angle $\varphi_{0}=21^{0}$ and the specific adhesion $c=3 \mathrm{kPa}$, for which in the calculation was set: the deformation modulus $E=45 \mathrm{MPa}$, the Poisson's ratio $v=0.3$, the density $p_{0}=1700 \mathrm{~kg} / \mathrm{m}^{3}$, the critical density $p^{*}=$ $1690 \mathrm{~kg} / \mathrm{m}^{3}$. Before installing the shell, the layer of medium-grained sand of $10 \mathrm{~cm}$ thickness was laid on the soil, which was leveled according to a special template. The following physical and mechanical characteristics of sand were accepted: the internal friction angle $\varphi_{0}=35^{\circ}$, the specific adhesion $c=1 \mathrm{kPa}$, the deformation modulus $E=45 \mathrm{MPa}$, the Poisson's ratio $v=0.3$, the density $p_{0}=$ $1630 \mathrm{~kg} / \mathrm{m}^{3}$, the critical density $p^{*}=1600 \mathrm{~kg} / \mathrm{m}^{3}$. Due to the fact that according to the tests results [7] the depletion of bearing capacity occurred at a significant intensity of the reactive pressure under the foundation glass part $P=0.52 \mathrm{MPa}$, the method was not taken into account.

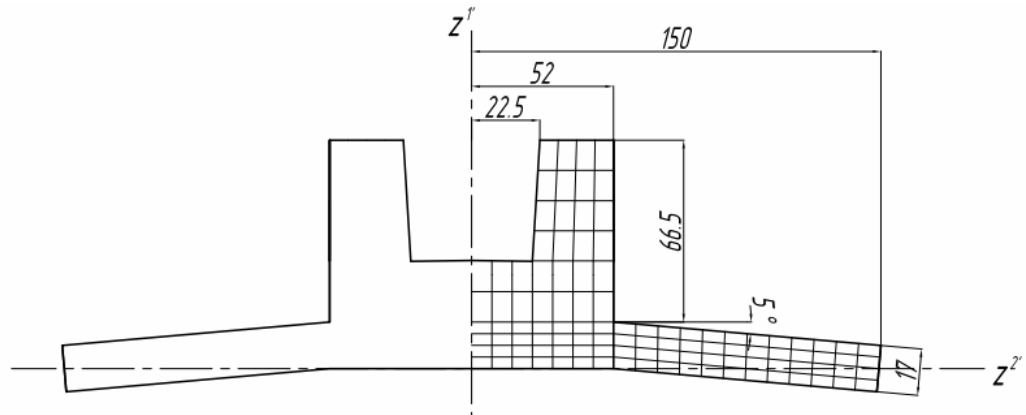

Fig. 4. Computational scheme of the foundation-shell: $\mathrm{a}$ - the discrete model; $\mathrm{b}$ - the structure dimensions and the $\mathrm{CE}$ grid 
The discrete model of the foundation-shell with the adjacent area of the base, presented in Fig. 4 and 5, is developed taking into account the experience of similar calculations $[1,4,5,6]$. In the numerical study the load was simulated by forced displacements of the foundation glass bottom with the step of $\Delta U=0.02 \mathrm{~cm}$. To assess the effect of nonlinear strength of materials of the structure and the base for the predicted level of bearing capacity, three calculations were executed: 1) the structure and the soils were simulated linearly elastic; 2) the plastic deformations in the structure were considered; 3) physically nonlinear work of all materials was taken into account.

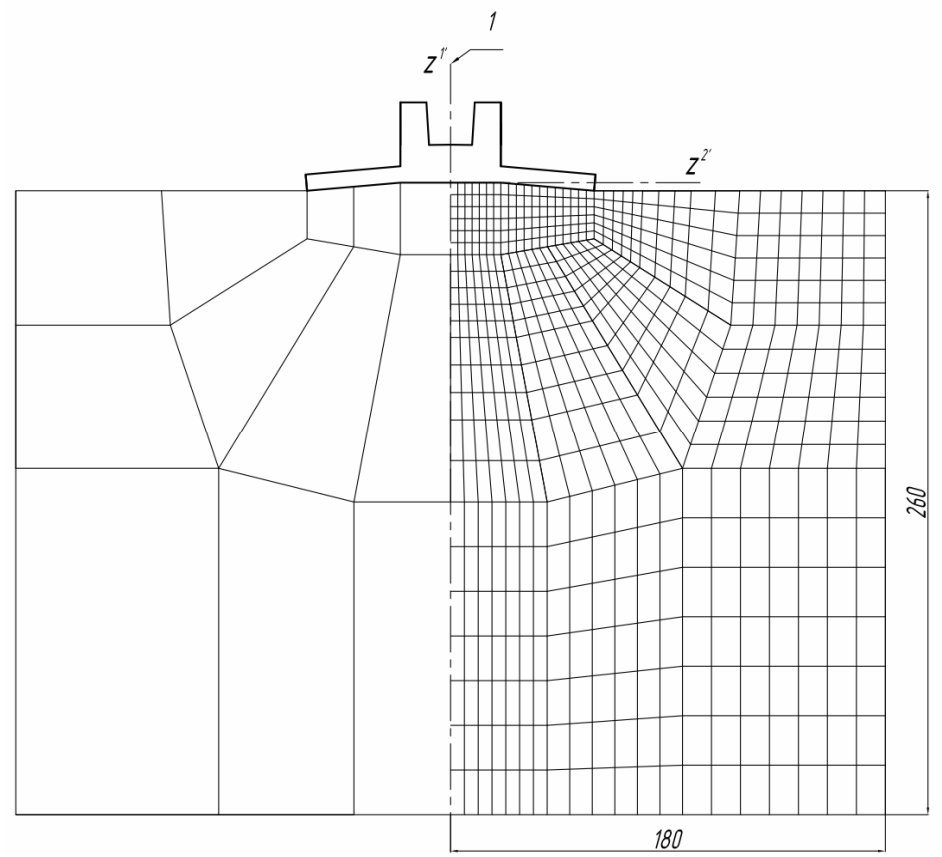

Fig. 5. Computational scheme of the foundation-shell and the adjacent area of the base (1rotation axis): $\mathrm{a}$ - the discrete model structure; $\mathrm{b}$ - the dimensions (in $\mathrm{mm}$ ) and the CE grid

Analysis of the calculation results showed the following. Graphs of the function vertical load $Q$ - the displacement of the foundation glass bottom $U$ (Fig. 6) allow us to judge the sudden nature of the bearing capacity depletion. The calculation data of possible cracking zones agree well with the experimental ones [7]. Thus, according to the strain gauges, the first to appear were the circumferential cracks on the foundation lower surface in the area where the conical shell and the rigid glass part meet. Similar data were obtained by calculation. Moreover, the numerical method has the advantage over the natural experiment, which allows you to track not only the possible formation and development of cracks that reach the structure visible surface, or in a limited number of points where the strain gauges are installed, but also the origin and subsequent growth during loading of all possible cracking zones. Following the 
first circumferential cracks in the immediate vicinity of them on the lower surface of the shell formed the zone of meridional cracks, which with increasing load rapidly progressed in the radial direction and, reaching the lower base of the cone, came to the visible surface, where they spread to the upper foundation glass base. The values of the vertical load $Q$ and the displacement of the glass bottom $U$, correspond to the calculation results in the statement (3) (taking into account the plastic features of the structure and the soil).

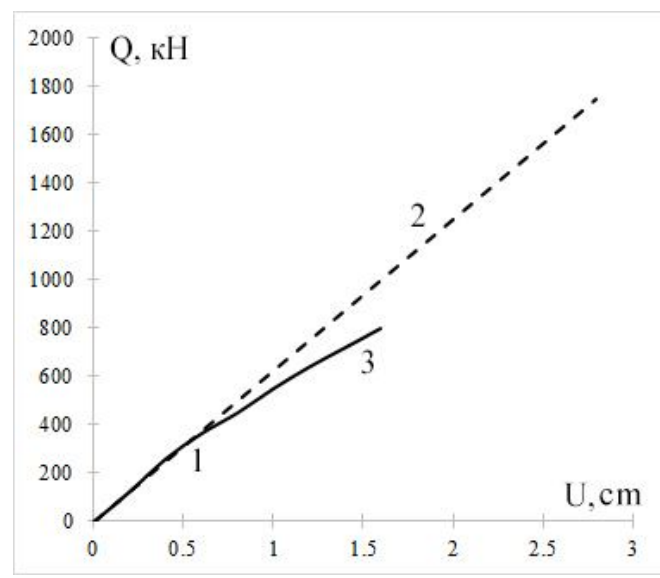

Fig. 6. The graph of the vertical load function $\mathrm{Q}$ - the glass bottom displacement $\mathrm{U}$ : 1 - the construction and the soil are linearly elastic; 2 - taking into account the structure plastic deformations; 3 - taking into account the plasticity of all materials

According to [7], the foundation-shell destroyed "according to the meridional scheme with the annular plastic hinge formation at the junction of the conical shell and the rigid glass part". However, the remark of this work authors that after the experiment termination "the glass displacement (subsidence) relative to the hard disks was $0.05-0.08 \mathrm{~m}$ ", raises doubts about the plastic hinge formation. Most likely in the experiment, as well as in the calculation, the reason for the bearing capacity depletion was the destruction (cut) of the structure compressed material and the formation of the through circumferential crack in the area of the shell adjacency to the glass. Therefore, using the terminology [12], we can conclude that the reason for the bearing capacity depletion of this structure was the destruction due to the cut of the compressed concrete zone.

Table 1 shows the comparison of the computational values of the load $Q^{v}$ at which the meridional crack arrays came to the upper surface of the shell, and the structure bearing capacity $Q^{*}$ with the relevant experimental data. $Q_{e}^{v}=450 \mathrm{kN}, Q_{e}^{*}=900 \mathrm{kN}$. The minimum values of these characteristic loads are obtained under the assumption of the linear-elastic operation of the structure and the soil: $Q^{v}{ }_{1}=456,1 \mathrm{kN}, Q^{*}{ }_{1}=632,5 \mathrm{kN}$. As expected, taking into account the structure plastic deformations led to the likely redistribution of stresses, as well as to the load increase at which is possible the formation of 
meridional cracks, and the bearing capacity to the values $Q_{2}^{v}=456,1 \mathrm{kN}$, $Q_{2}^{*}=632,5 \mathrm{kN}$, accordingly. Finally, the additional consideration of the physical and nonlinear work of the soil base has led to less favorable conditions for the operation of the foundation-shell structure and decrease of the control loads values: $Q_{3}^{v}=489,5 \mathrm{kN}, Q_{3}^{*}=881,8 \mathrm{kN}$. Therefore, upon the fullest consideration of all factors of physical nonlinear strength of structural materials and soils, the calculated level of the bearing capacity $Q^{*}{ }_{3}$ is only $2.0 \%$ less than the experimental value of $Q_{e}^{*}$.

Table 1

\begin{tabular}{|c|c|c|c|c|}
\hline $\begin{array}{c}\text { Graph } \\
\text { number }\end{array}$ & $Q^{v}, \mathrm{\kappa H}$ & $\frac{Q^{v}-Q_{e}^{v}}{Q_{e}^{v}} \cdot 100 \%$ & $Q^{*}, \mathrm{\kappa H}$ & $\frac{Q^{*}-Q_{e}^{*}}{Q_{e}^{*}} \cdot 100 \%$ \\
\hline 1 & 456.1 & 1.4 & 632.5 & -29.7 \\
\hline 2 & 603.9 & 34.2 & 1818.5 & 102.1 \\
\hline 3 & 489.5 & 8.8 & 881.8 & -2.0 \\
\hline
\end{tabular}

Conclusions. Therefore, the use of the developed method allows to significantly specify the structures stress state interacting with the soil base, and to significantly specify the impact on the calculated level of the base bearing capacity. Only the simultaneous consideration of the nonlinear resistance of the soil base together with the plasticity and the structure destruction in the numerical simulation of the foundation-shell load provided good agreement with the natural experiment data as to the type of the boundary state and the bearing capacity level.

\section{REFERENCES}

1. Boyandin V.S. Non-linear processes of interaction of reinforced concrete foundations with soil Non-linear processes of interaction of reinforced concrete foundations with soil / V.S. Boyandin, I.A, Semenetc, A.L. Kozak// Problemy chislennogo modelirovaniia i avtomatizatcii proektirovaniia inzhenernykh konstruktcii. Sb. tr./ Pod red. Kandaurova I I. i Snitko A.N. Leningrad: Izd-vo LIIZHT, - 1987. - P.41-89.

2. Boyko I.P. Progressive methods of designing foundations and foundations on computers. / I.P. Boyko - Kiev: Znanie, 1986. - 20 p.

3. Boyko I.P. Tense-deformed state of elastic-plastic dilating base of pile foundations / I.P.Boyko // Osnovaniia i fundamenty`. - 1986. - Issue. 19. - P. 10-12.

4. Boyko I.P. Numerical modeling of the process of cracking in the reinforced concrete foundation-shell on elastic-plastic base / I.P. Boyko, V.S. Boyandin, A.E Delnik et al. // Issledovaniia i razrabotki po komp iuternomu proektirovaniiu fundamentov i osnovanii, Novocherkassk, Izd-vo NPI. - 1990. - P.21-27.

5. Boyko I.P. The nonlinear processes during the interaction of reinforced concrete structures with the subsoil / I.P. Boyko, V.S. Boyandin, A.E Delnik et al. // European mechanics colioguium/248 "Non linear Soil structures interaction"10. - April 11-14, 1989, Grenoble, France. - P.142-145.

6. Boyko I.P. Finite element simulation of the stable resistance in a foundation soil system / I.P. Boyko, V.S. Boyandin, A.E. Delnik et. al. // Archive of Appl. Mech. - 1992 - N.62 - P.316328.

7. Climanov V.I. Conical shell foundations. / V.I. Climanov, A.G. Leetvinenko, V.P. KanaevaM- Stroyizdat, 1988. $-128 \mathrm{p}$.

8. Kroner E. Elasticity theory of materials with long-range cohesive forces / E. Kroner // Int. J. Solids and Struct. $-1967 .-$ N 3. - P.731-742. 
9. Report on engineering and geological research at the N4 n Kiev Dairy Plant - Kiev: GPI "Iugozapadpromiaso-molprom". - Albom 2. Kn. 1. - 70 p.

10. Schweiger H.F. Examples of successful numerical modelling of complex geotechnical problems / H.F. Schweiger et al. // Innovative Infrastructure Solutions. - 2019. - T. 4. - №. 1. - C. 2.

11. Solodei I.I. Nonlinear problem of structural deformation in interaction with elastoplastic medium / I.I. Solodei, E.Yu. Petrenko, Gh.A. Zatyliuk // Strength of Materials and the Theory of Structures. - 2020. - Issue 105. - P.49-64.

12. Tetior A.N. Shell foundations. / A.N. Tetior, A.G. Leetvinenko M.: Stroiizdat, 1975. - 136 p.

Стаття надійшла 11.03.2021

Вабімевич М.О.., Затилюк Г.А.

\section{АНАЛІЗ НАПРУЖЕНО-ДЕФОРМОВАНОГО СТАНУ ФУНДАМЕНТУ-ОБОЛОНКИ ПРИ ВЗАЕМОДІЇ ІЗ ПРУЖНОПЛАСТИЧНИМ СЕРЕДОВИЩЕМ}

У статті на базі сучасних чисельних реалізацій метода скінченних елементів представлено обгрунтування адекватності методики розв'язання задач деформування конструкцій при їх контактній взаємодії із пружнопластичним нелінійним грунтовим середовищем.

Врахування методики побудови розрахункових моделей сумісного деформування i взаємного впливу жорстких конструкцій і суттєво пластичного зовнішнього середовища дозволяє істотно уточнити напружений стан конструкцій, взаємодіючих 3 грунтовою основою, і робить помітний вплив на розрахунковий рівень несучої здатності основи.

Ключові слова: пружнопластичне середовище, метод скінченних елементів, напіваналітичний метод скінченних елементів, задача деформування конструкцій.

Vabishchevich M.O., Zatyliuk Gh.A.

ANALYSIS OF THE STRESSED-STRAINED STATE OF THE FOUNDATION-SHELL AT INTERACTION WITH THE ELASTIC-PLASTIC MEDIUM

On the basis of modern numerical implementations of the finite element method the article presents the justification of the adequacy of the method of solving the problems of structures straining in their contact interaction with the elastic-plastic nonlinear soil medium.

Compatible calculations of structures and nonlinear bases, which are described by modern mechanical and soil models within one problem is a significant technical problem.

The solution of the assigned tasks is possible only within the framework of numerical methods, the most common of which is the finite element method (FEM). The construction of the computational finite element model raises many complex questions that require additional detailed study. In addition, the compliance with the state building norms and regulations is an important factor for further practical use.

The use of numerical methods in the calculation of machines and structures, taking into account their interaction with the elastic-plastic medium is largely determined by the complexity or even impossibility of analytical calculation due to the complexity of structural schemes, heterogeneity of material features, uneven soil layers, implementation of step-by-step work execution technologies and so on.

The combination of the latest achievements in the field of structural mechanics and soil mechanics is a promising direction for the development of effective approaches to building discrete models of space systems "structure-nonlinear base" for solving applied problems.

The use of the developed method allows to significantly specify the structures stress state interacting with the soil base, and to significantly specify the impact on the calculated level of the base bearing capacity. Only the simultaneous consideration of the nonlinear resistance of the soil base together with the plasticity and the structure destruction in the numerical simulation of the foundation-shell load provided good agreement with the natural experiment data as to the type of the boundary state and the bearing capacity level.

Keywords: elastic-plastic medium, finite element method, semi-analytical finite element method, structure straining problem. 
Вабищевич М.О.., Затылюк Г.А.

\section{АНАЛИЗ НАПРЯЖЕННО-ДЕФОРМИРОВАННОГО СОСТОЯНИЯ ФУНДАМЕНТА- ОБОЛОЧКИ ПРИ ВЗАИМОДЕЙСТВИИ С УПРУГОПЛАСТИЧЕСКОЙ СРЕДОЙ}

В статье на базе современных численных реализаций метода конечных элементов представлено обоснование адекватности методики решения задач деформирования конструкций при их контактном взаимодействии с упругопластической нелинейной грунтовой средой.

Учет методики построения расчетных моделей совместного деформирования и взаимного влияния жестких конструкций и существенно пластической внешней среды позволяет уточнить напряженное состояние конструкций, взаимодействующих с грунтовым основанием, и оказывает заметное влияние на расчетный уровень несущей способности основания.

Ключевые слова: упругопластическая среда, метод конечных элементов, полуаналитический метод конечных элементов, задача деформирования конструкций.

\section{УдК 539.3}

Вабіщевич М.O., Затилюк Г.А. Аналіз напружено-деформованого стану фундаментуоболонки при взаємодії із пружнопластичним середовищем // Опір матеріалів і теорія споруд: наук.-тех. збірник - К.: КНУБА, 2021. - Вип. 106. - С. 105-112. - Англ.

Представлено обтрунтування адекватності методики розв'язання задач деформування конструкиій при їх контактній взаємодії із пружнопластичним нелінійним грунтовим середовищем.

Іл. 6. Бібліогр. 12 назв.

\section{UDC 539.3}

Vabishchevich M.O., Zatyliuk Gh.A. Analysis of the stressed-strained state of the foundationshell at interaction with the elastic-plastic medium // Strength of Materials and Theory of Structures: Scientific-and-technical collected articles. - K.: KNUBA, 2021. - Issue 106. - P. 105 112.

Presents the justification of the adequacy of the method of solving the problems of structures straining in their contact interaction with the elastic-plastic nonlinear soil medium.

Fig. 6. Ref. 12 titles.

\section{УДК 539.3}

Вабищевич М.O., Затылюк Г.А. Анализ напряженно-деформированного состояния фундамента-оболочки при взаимодействии с упругопластической средой // Сопротивление материалов и теория сооружений: науч.-тех. сборн. - К.: КНУСА, 2021. Вып. 106. - С. 105-112. - Англ.

Представлены обоснования адекватности методики решения задач деформирования конструкиий при их контактном взаимодействии с упруго нелинейной грунтовой средой.

Ил. 6. Библиогр. 12 назв.

Автор: доктор технічних наук, професор, професор кафедри будівельної механіки ВАБІЩЕВИЧ Максим Олегович

Адреса: 03680 Украӥна, м. Київ, Повітрофлотський проспект 31, Київський національний університет будівництва і архітектури

Робочий тел.: +38 (044) 241-55-55

Мобільний тел.: +38 (050) 928-40-97

Email: vabischevych.mo@knuba.edu.ua

ORCID ID: http://orcid.org/0000-0002-0755-5186

Автор: аспірант, асистент кафедри будівельної механіки ЗАТИЛЮК Герман Анатолійович Адреса: 03037 Украӥна, м. Київ, Повітрофлотський проспект 31, Київський начіональний університет будівництва і архітектури

Мобільний тел.: +38 (099) 11-00-564

Email: zatyliuk.ha@knuba.edu.ua

ORCID ID: https://orcid.org/0000-0003-0392-2214 